\title{
Rural Banks Stability Index: The Case of Bali
}

\author{
Fridayana Yudiaatmaja ${ }^{1, *}$ Wayan Bagia ${ }^{1}$ Nengah Suarmanayasa ${ }^{1}$ Made Suci $^{1}$ \\ ${ }^{l}$ Department of Management, Universitas Pendidikan Ganesha, Singaraja, Indonesia. \\ ${ }^{*}$ Corresponding author. Email: fyudiaatmaja@gmail.com
}

\begin{abstract}
Banking stability is variable need to be concerned in order to avoid financial crisis, especially for countries whose financial structure is dominated by banking institutions. Many researchers are interested in developing the banking stability index, but few specifically develop the rural banks stability index. This study aims to develop the rural banks stability index in the case of rural banks in Bali, Indonesia. The latent variable of banking stability was measured using four components, namely capital, asset quality, profitability and liquidity. The indicators used to measure the stability's components are adjusted to the characteristics of rural banks and existing regulations. The results showed that the Rural Banks Stability Index (RBSI) was between $0.35-0.44$. Based on stability's cut-off point of 0.2765 , it can be concluded that the stability of rural banks in all areas of Bali during the study period is stable.
\end{abstract}

Keywords: Financial crisis, Banking stability, Rural bank stability index.

\section{INTRODUCTION}

[1] stated that in the period 1800-1970 there have been 121 banking crises around the world. [2] stated that in the period 1970-2007 there were 124 banking crises. Therefore, it can be stated that the banking crisis is still likely to occur at any time. The development of knowledge and technology does not necessarily rule out the possibility of banking crisis to happen.

Banks have the opportunity to survive in the midst of a crisis by having adequate capital. However, how much capital is needed to survive in the midst of a crisis is a question that is not easy to answer given the uncertainty about how severe the crisis will be.[3] explained that there are five capital adequacy ratios used by banks in America as a reference in order to survive in the midst of a crisis, namely the capital ratio, tier 1 ratio, common equity tier 1 (CET1) ratio, leverage ratio, and supplemental leverage ratio. Leverage ratio and supplemental ratio are ratios that are not based on risky assets, while capital ratio, tier 1 ratio, common equity tier 1 (CET1) ratio are ratios that pay attention to risk aspects in assets [3]. The ratio by taking into account the risk aspect of assets means that the riskier the bank's assets, the more capital buffer needed to cover losses. However, all of the capital adequacy ratios cannot provide sufficient information to survive in the midst of a crisis [4].
Given the uncertainty over how severe the banking crisis will be in the future, it is important for financial services authorities to monitor banking stability on a regular basis. This is even more for countries that have a financial structure dominated by banking institutions, such as in Indonesia [5].By maintaining banking stability, the banking crisis is expected to be avoided so that the economy can run as expected.

Many researchers have conducted studies on banking stability [6]; [7] however, there is little empirical evidence analyzing the stability of rural banks. In Indonesia, rural banks are known as Bank Perkreditan Rakyat (BPR). Based on data provided by [8] as a financial authority in Indonesia, in 2019 the number of loans disbursed by commercial banks to nonbank third parties in Bali was Rp. 81,273 trillion. The amount of credit disbursed is indeed much larger than the amount of credit disbursed by rural banks in Bali, which was Rp. 11.287 trillion [8]. However, the amount of credit disbursed by rural banks was also not small or equal to 13.88 percent of the total credit of commercial banks. Therefore, research related to the banking stability, specifically on rural banks, is also very necessary to obtain a complete and comprehensive banking stability condition.

The contribution of this study to the literature related to the measurement of banking stability is by adopting 
individual bank financial soundness indicators that are adapted to the characteristics of rural banks and regulations in Indonesia. The composite value of rural banks stability is obtained by combining the components/dimensions and indicators according to the method used by [6] in assessing banking stability in several European countries. By using the same method in producing a composite value of banking stability, the stability condition of rural banks can be compared with other banking stability conditions. The contribution of this research is also to determine the cut-off point that distinguishes rural bank stability in stable and unstable condition.

[9] stated that as many as more than 130 countries or two thirds of the IMF's members have experienced serious banking problems since 1980 . Costs incurred to deal with the crisis averaged 5.6\% of Gross Domestic Product [10]. Due to the enormous costs involved in dealing with banking crises, the central bank and financial services authorities seek various ways to predict, anticipate and even if possible avoid a banking crisis..

To anticipate the occurrence of a banking crisis, it is important for financial services authorities and banking institutions to conduct stress tests to determine the bank's resilience to potential disturbance that could threaten the sustainability of the bank's business. The Federal Reserve usually runs stress tests to simulate baseline, adverse and severe adverse scenarios based on assumptions of economic variables, such as GDP, unemployment, interest rates, in a state of distress [3] Predicting when a crisis will occur in the future can be assisted by building an Early Warning System (EWS). [11] stated that Financial Stability Reviews are the initial stage carried out by EWS to help the authorities identify potential risks that may occur in th future.

Financial stability is defined as a condition in which the financial system consisting of financial institutions, financial markets and financial infrastructure can accept shocks and harmonize with existing conditions so as to reduce the possibility of disruptions in the financial intermediation process thereby significantly changing the allocation of savings become a profitable investment opportunity [12] Financial instability is defined as a condition where a number of bank customers fail to pay and a number of banks experience liquidity difficulties without having to go bankrupt, resulting in a significant decline in the profitability of the banking sector [13]

\subsection{Banking Stability Indicators}

[14] conducted research on financial stability by using four factors, namely financial system development, financial system vulnerability, banking stability, and the global economy. The four financial stability factors are represented as Financial Development Index (FDI), Financial Vulnerability
Index (FVI), Financial Soundness Index (FSI), and World Economic Climate Index (WECI). All of these components are measured using 20 indicators. The results indicated that the index aggregate formed successfully describes the condition of the banking crisis in Romania in the period 1998-1999 and the subprime crisis in 2007.

Research on financial stability is indeed broader than research on banking stability because banking is part of the financial system. [14] stated that banking stability is represented using the Financial Soundness Index with four indicators, namely non-performing loans to total loans, regulatory capital to risk weighted assets, owner's capital to total assets, and effective liquidity to required liquidity. [15] also conducts a study on financial stability which is stated that Financial Soundness Indicators (FSIs) using 40 indicators consisting of 12 core indicators (Core Financial Soundness Indicators) and 28 supporting indicators.

Research related to banking stability indicators was specifically carried out by Powell and Vo (2020) by developing a comprehensive stability indicator (CSI). CSI consists of three factors, namely Creditworthiness, Conditions and Capital (3Cs). Creditworthiness is an internal factor measured by using NPL to total gross loans, The external factor measured using market asset value volatility of banks. Capital is measured by using the ratio of total capital to total assets.

[16] stated that banking stability is based on four risks, namely asset/portfolio risk, insolvency risk, illiquidity risk, and systemic risk. These risks are measured using several indicators such as NonPerforming Loans (NPL), z-score, distance to default, and other accounting data.

[17] developed Systemic Risk Accumulation Index (SRMI) using principal component analysis to measured banking stability. It was also emphasized that there is no agreement on the models and indicators used to measure banking stability. Many studies in various countries seek to identify conditions that can ensure the maintenance of stable financial conditions resulting the main indicators known as CAMELS (C - Capital Adequacy, A - Asset Quality, M - Management, E Earning, L - Liquidity, S - Sensitivity to Market Risk).

In this research, rural banks stability is measured based on four components, namely capital, productive asset quality, earnings, and liquidity. The four components are latent variables that cannot be measured directly. The operational measure of each indicator is adjusted based on the availability of data on rural banks (BPRs) at the Financial Services Authority in Indonesia as stated in the following regulation SE OJK No. 39/SEOJK.03/2017. 


\subsection{Banking Stability Measurement}

[18] stated that the banking system is conceptually a portfolio of banks. Banking stability is expressed as a bank's individual risk and systemic risk (the risk that occurs in the entire banks). [19] stated that banking stability can be measured in two ways, namely:

\subsubsection{Firm-level Stability Measures}

In 1979, banking institutions in America implemented the Uniform Financial Institutions Rating System (UFIRS) to assess bank performance[20]. The system was widely developed, and then internationally known as the CAMEL method. This method assesses the performance of individual banks based on five areas of assessment, namely capital, asset quality, management, earnings and liquidity. With the development of the global financial system, this method later became CAMELS to accommodate market risk. [21] stated that CAMELS is a method that has a significant ability to detect financial distress. [22] combining CAMELS with data envelopment analysis to measure bank stability.

Another method commonly used to measure individual bank stability is the $\mathrm{z}$-score. The calculation of the z-score used by researchers generally refers to the formula used by [23] as follows.

$$
z=\frac{(k-\rho)}{\sigma}
$$

Where $\mathrm{k}=-$ Equity / Assets, $\rho$ is the average of the return distribution $(\hat{\mathrm{r}}), \sigma$ is the standard deviation and $\mathrm{z}$ is the probability of default. The bank is declared default if the value of $\hat{r}$ (Profits / Assets) smaller than the value of $\mathrm{k}$. The performance of one bank with another is compared not only based on return but also based on risk. Therefore, some research use the value of Tobin's q in assessing the distribution of returns.

In addition to calculating the z-score to measure the stability of individual banks, researchers can also use the Merton model, which is also known as the asset value model. This model measures the ability of banks to meet their obligations when debt holders will exercise their options to obtain repayment. Options pricing is obtained from the Black-Scholes equation [24].

$$
\begin{gathered}
C_{\text {call }}=S \emptyset\left(d_{1}\right)-X e^{-r T} \emptyset\left(d_{2}\right) \\
P_{p u t}=X e^{-r T} \emptyset\left(-d_{2}\right)-S \emptyset\left(-d_{1}\right)
\end{gathered}
$$

Where

$$
\begin{gathered}
d_{1}=\frac{\log \left(\frac{S}{X}\right)+\left(r+\frac{\sigma^{2}}{2}\right)}{\sigma \sqrt{T}} \\
d_{2}=d_{1}-\sigma \sqrt{T}
\end{gathered}
$$

$\mathrm{C}_{\text {call }}$ - call options price, $\mathrm{P}_{\text {put }}$ - put options price, $\mathrm{S}$ stock price, $\mathrm{X}$ - stock strike price, $\mathrm{r}$ - risk-free asset rate, $\mathrm{T}$ - time until options expire in years, $\sigma$ - stock volatility, $\varnothing-$ normal distribution cumulative function.

If $\mathrm{E}$ is company equity, $\mathrm{D}$ is debt and $\mathrm{A}$ is asset, then the payment to shareholders at time $\mathrm{T}$ is as follow [25]

$$
E_{T}=\max \left[A_{T}-D, 0\right]
$$

If the company's equity is a call option with the strike price being a debt payment, then the current value of the company's equity can be written as follows.

$$
E_{0}=A_{0} N\left(d_{1}\right)-D e^{-r T} N\left(d_{2}\right)
$$

Where

$$
\begin{gathered}
d_{1}=\frac{\ln \left(\frac{A_{0} e^{r T}}{D}\right)}{\sigma_{A} \sqrt{T}}+\frac{1}{2} \sigma_{A} \sqrt{T} \\
d_{2}=d_{1}-\sigma_{A} \sqrt{T}
\end{gathered}
$$

he probability of default $(\mathrm{P})$ is calculated using the following equation.

$$
P=N\left(-d_{2}\right)
$$

If leverage $L=\frac{D e^{-r T}}{A_{0}}$, then the credit risk in the Merton model is as follows.

$$
s=-\ln \frac{\left[N\left(d_{2}\right)+\frac{N\left(-d_{1}\right)}{L}\right]}{T}
$$

Furthermore, researchers also have the option to use Distance to Default which can measure the marketbased default risk of a bank. Distance to Default is a development method of the Merton model. Distance to Default (DD) is obtained through the following formula [26]

$$
\mathrm{DD}=\frac{\ln \left(\frac{A_{t}}{D_{t}}\right)+\left(r+\frac{\sigma_{A}^{2}}{2}\right)(T-t)}{\sigma_{A} \sqrt{T-t}}
$$

\subsubsection{Systemic Stability Measures}

Systemic stability measures can be obtained by combining the overall firm-level stability values. Firmlevel stability can be combined by finding the average value or by giving weight to the stability components. In addition, the First-to-Default Probability method can be used to assess systemic risk by taking into account the first bank to default. Another method that can be used to measure systemic financial stability is the Systemic Expected Shortfall (SES) which looks at the potential of each bank in generating systemic risk. SES is stated to be very difficult to determine when important institutions will experience systematic default.

\subsection{Banking Stability Rating}

Many studies have been conducted related to banking stability, such as [6]; [27] or [14], but does not provide an explanation of the level of stability that 
distinguishes stable and unstable conditions. In the CAMELS method used to assess the firm-level stability measure, the bank's financial condition is classified into five composite ratings, namely 1, 2, 3, 4, and 5 [28]

[28] explained that institutions with a rating of 1 and 2 are grouped into strong banks, while institutions with a rating of 3,4, and 5 are classified as weak banks. This classification also results in the finding that strong banks have significantly better efficiency levels than weak banks. The results of the research regarding the level of efficiency are stated to be consistent during the 15 year research period.

In Indonesia, rural banks soundness level assessment is set at SK Direksi No. 30/12/KEP/DIR/1997 issued by Bank Indonesia. The regulation explains that each ratio used to measure the soundness level which consists of components of capital, productive asset quality, management, profitability and liquidity is converted into a credit score from a value range of 0 to 100 . Furthermore, to obtain a composite score, each the CAMEL component is multiplied by its weight. Based on the results of the composite score, rural banks are classified into four, namely sound, adequately sound, less sound and unsound.

\section{METHOD}

\subsection{Research Design}

This research is a descriptive research with a quantitative approach. Quantitative approach is used because this research seeks to describe phenomena through quantitative data. The variable used in this study is stability which is the latent variable. The latent variable is described through four components with their respective indicators.

\subsection{Data Collection}

The data source of this research is secondary data. Secondary data is research data sourced from other parties. In this research, secondary data is taken friom financial services authority, in Indonesia which is known as Otoritas Jasa Keuangan (OJK). Based on the availability and completeness of data at the Financial Services Authority in Indonesia, this study uses data from 2012 to 2019. During the study period there were 133 banks, but not all rural banks were included in the study. Rural banks that have completed data according to research purposes were 120 banks.

\subsection{Method of Analysis}

In the literature review, it is explained that measuring banking stability can use the z-score method or measure credit risk as used in the Merton model, or by measuring Distance-to-Default. In this study, the stability of rural banks in Indonesia (BPR) is measured using financial soundness indicators in accordance with
[29] This method was chosen not only because the characteristics of rural banks are different from commercial banks, but also the availability of the data. In the regulation regarding rural banks, financial soundness indicators are divided into four dimensions/components, namely Capital, Assets Quality, Profitability and Liquidity.

The Capital component is based on the ratio of Total Capital to Risk Weighted Assets (RWA). Total capital is the sum of core capital (tier-1) and supplementary capital (tier-2). RWA is the number of assets that are weighted according to the level of risk. This capital ratio is known as Kewajiban Penyediaan Modal Minimum (KPMM) in Indonesian term or commonly known as Capital Adequacy Ratio (CAR). Components of Assets Quality are measured using two indicators, namely: (1) the ratio of Non-performing Earning Assets (Aktiva Produktif Yand Diklasifikasikan - APYD) to Total Productive Assets; and (2) the ratio of Provision for Loan Losses (Penyisihan Penghapusan Aktiva Produktif - PPAP) established to PPAP that must be established by banks. Profitability component is measured using two indicators, namely: (1) the ratio of Profit Before Tax in the last 12 months to the average Business Volume in the same period; and (2) Ratio of Operating Expenses in the last 12 months to Operating Income in the same period. The Liquidity component is measured using two indicators, namely: (1) Ratio of Liquid Assets to Current Debt; and (2) Ratio of Credit to Funds Received by the bank.

Before all of the indicator values used to calculate the Rural Banks Stability Index, the indicators that have a negative impact on stability need to be adjusted by using its reciprocal value. Furthermore, all of the indicators is normalized or converted to have uniform data distribution information. [14] stated that there are four ways of normalization commonly used, namely:

1) Statistical normalization; All values are adjusted using the standard deviation so that the mean is zero.

2) Empirical normalization; All values are adjusted using the formula $\mathrm{Y}=(\mathrm{X}-$ Min)/(Max - Min) so that the resulting value is in the interval 0 and 1.

3) Axiological normalization; This method is carried out not using statistics, but using an empirical approach to the minimum and maximum values.

4) Mathematical normalization; This method transforms data using mathematical functions so that the value is between the desired upper and lower limits, for example between 0 and 1 or between -1 and 1 . 
Systemic stability value or Rural Banks Stability Index (RBSI) is obtained by adding up the multiplication of stability components with their respective weights. Determination of weights can be done in various ways, such as expert judgment, standardization (variance-equal weights), market segmentation size, coefficient of the first factor in factor analysis, logit model estimation and so on [6] This research used similar proportion to the four components as done by [6] to calculate banking stability for several European countries.

The soundness level of Rural Banks Stability Index is summarized into two, namely Stable and Unstable, which is set based on SK Direksi Bank Indonesia No. 30/12/KEP/DIR/1997. Soundness level of Sound and Adequately Sound are classified into Sable, whereas soundness level of Less Sound and Unsound are classified into Unstable. The cut-off point value to distinguish Stable and Unstable conditions obtained based on these regulations is 0.2765 . This classification method is not similar to [28] who summarized individual bank into Strong and Weak.

\section{RESULTS \& DISCUSSION}

\subsection{Data Collection}

The secondary data is collected from Financial Services Authority in Indonesia. Based on the availability and completeness of the data, this research used data from the period of 2012 to 2019. During the study period there were 133 banks, but not all rural banks were included in the study. There are 120 rural banks that have sufficient data according to research purposes.

\subsection{Analysis}

Bali consists of eight regencies, namely Bangli, Badung, Buleleng, Gianyar, Jembrana, Karangasem, Klungkung and Tabanan. In addition to eight regencies, Bali has one municipality, namely Denpasar. Badung is the area with the highest number of banks, which is as many as 49 rural banks. Jembrana is the area with the least number of banks, which is only one bank.

Based on the data collected, the total amount of credit from rural banks in all areas of Bali in 2012 was Rp. 3,448,124,105,000 and then in 2019 it was Rp. $10,828,096,959,000$. There is an increase in the average number of loans every year by $14 \%$. In 2019, Denpasar was the area with the largest number of loans (Rp. $5,414,865,336,000)$ and Jembrana was the region with the smallest number of loans (Rp. 5,880,664,000).

The credit quality of rural banks calculated based on the ratio of non-performing loans (NPL) in Bali at the end of 2012 was 3.30. At the end of 2019, the NPL in Bali had increased to 11.50 . Almost every year there is an increase in NPL, except in 2019 there was a decrease in NPL. The average increase in NPL every year is $22.8 \%$.

To be able to calculate the stability of rural banks, the first step is to adjust the value of each indicator that has a negative impact on stability. The second step is to calculate the normalization of each stability indicator. The third step is to calculate the value of the stability components, namely capital, productive asset quality, profitability and liquidity. The value of each stability component can be obtained by finding the average of its indicators. After obtaining the value of each stability component, RBSI is calculated by adding up the stability components with their respective weights.

In this study, the stability condition of rural banks is classified into two, namely Stable and Unstable. The cut-off point value that separates Stable and Unstable conditions is calculated based on the criteria in SK Direksi Bank Indonesia No. 30/12/KEP/DIR/1997. The criteria for KPMM, KAP, PPAP, ROA, BOPO, LDR and Cash Ratio to determine cut-off point of stability are $8 \%, 12.6 \%, 66 \%, 1 \%, 93.5 \%, 98.5 \%$, and $3.3 \%$. After adjustment and normalization to all of those criteria, the cut-off point value is calculated by adding up the value of the stability components with its respective weight. From the calculation, the cut-off point value is 0.2765 .

From the calculation of the Rural Banks Stability Index in all regions in Bali, it was found that the highest value of 0.44 was in Buleleng and Gianyar, while the lowest value was 0.35 in Jembrana. All areas in Bali have an RBSI above 0.2765 , so all areas are stated to be in a stable condition during the period of research (Table 1).

Table 1 Rural Banks Stability Index (RBSI)

\begin{tabular}{|l|l|l|}
\hline \multicolumn{1}{|c|}{ Region } & \multicolumn{1}{c|}{ Average } & Classification \\
\hline Bangli & 0.41 & Stable \\
\hline Badung & 0.42 & Stable \\
\hline Buleleng & 0.44 & Stable \\
\hline Denpasar & 0.43 & Stable \\
\hline Gianyar & 0.44 & Stable \\
\hline Jembrana & 0.35 & Stable \\
\hline Karangasem & 0.39 & Stable \\
\hline Klungkung & 0.42 & Stable \\
\hline Tabanan & 0.42 & Stable \\
\hline Bali & 0.43 & Stable \\
\hline
\end{tabular}

[6] conducted research on all European Union (EU) countries with the method of giving equal weight to each stability component resulting in Banking Stability 
Index (BSI) between 0.3-0.6. Only two countries, Luxembourg and Estonia, have a Banking Stability Index above 0.5. Most countries have a BSI between $0.3-0.5$. When compared with the stability of rural banks in Bali, the banking stability in all areas of Bali is not much different from those in the European Union.

\section{CONCLUSION AND RECOMMENDATION}

In this study, banking stability was measured in two ways, namely firm-level stability measures and systemic stability measures. Aspects used to measure firm-level stability measures are capital, assets quality, profitability and liquidity. Systemic stability is measured by calculating the firm-level stability measures in aggregate for all rural banks in Bali. The results show that the stability of rural banks in all areas of Bali is in a stable condition for the period of study. The conclusion is obtained from the value of Rural Banks Stability Index (RBSI) which is between 0.35 and 0.44 (above the cut-off point of the stability index of 0.2765). Overall, the RBSI of the province of Bali is at 0.43 .

Banking stability is variable need to be concerned in order to avoid financial crisis, especially for countries whose financial structure is dominated by banking institutions. In Indonesia, banks are classified into two, namely commercial banks and rural credit banks. Because rural banks are part of the banking system, it is also necessary to make efforts to maintain the stability of rural banks. To be able to maintain the stability of rural banks, of course, efforts are needed to measure the stability of rural banks. Therefore, the financial services authority should measure the stability of rural banks regularly. In addition, this study did not include data during the Covid-19 pandemic. Researchers who are interested in this field can conduct event studies by comparing the stability of rural banks before and after the pandemic to know the effect of the pandemic.

\section{REFERENCES}

[1] V. Deltuvaitè, Measuring The Costs Of Banking Crises: Theoretical And Practical Aspects. 2011.

[2] F. Valencia and L. Laeven, "Systemic Banking Crises: A New Database [Working Paper]," https://www.imf.org/en/Publications/WP/Issues/ 2016/12/31/Systemic-Banking-Crises-A-NewDatabase-22345, 2008. .

[3] R. E. García and S. Steele, "Stress testing and bank business patterns: A regression discontinuity study," J. Bank. Financ., 2020, doi: https://doi.org/10.1016/j.jbankfin.2020.105964.

[4] T. Schuermann, "Stress testing banks.," Int. J. Forecast., vol. 30(3), pp. 717-728, 2014, doi: https://doi.org/10.1016/j.ijforecast.2013.10.003.

[5] D. Zulverdi, F. Syarifuddin, and N. J. Prastowo, "Pengaruh Kinerja Dan Struktur Sistem Keuangan Terhadap Pertumbuhan Ekonomi Di Indonesia,” Bank Indones., 2005.

[6] K. Kočišová, "Banking Stability Index: A Cross-Country Study. 15th International Conference On Finance And Banking,” 2005.

[7] N. Abdul Karim, A. A. Muhamat, A. Roslan, S. Alwi, and M. Jaafar, "Bank Stability Measures in Dual Banking System: A Critical Review.," Adv. Bus. Res. Int. J., vol. 5(59), 2019, doi: https://doi.org/10.24191/abrij.v5i2.9992.

[8] Otoritas Jasa Keuangan, "Statistik Perbankan Indonesia-Desember 2019," https://www.ojk.go.id/id/kanal/perbankan/datadan-statistik/statistik-perbankanindonesia/Documents/Pages/StatistikPerbankan-Indonesia---Desember2019/SPI\%20Desember\%202019.pdf, 2009. .

[9] M. I. Saal, C.-J. Lindgren, and G. G. (1996) Garcia, Bank Soundness and Macroeconomic Policy. In Bank Soundness and Macroeconomic Policyl, 1996.

[10] E. P. Davis and D. Karim, "Comparing early warning systems for banking crises.," J. Financ. Stab., vol. 4 (2), pp. 89-120, 2008, doi: https://doi.org/10.1016/j.jfs.2007.12.004.

[11] E. P. Davis and D. Karim, "Comparing early warning systems for banking crises.," J. Financ. Stab., vol. 4(2), pp. 89-120, 2008, doi: https://doi.org/10.1016/j.jfs.2007.12.004.

[12] B. Gadanecz and K. Jayaram, Measures of financial stability $-A$ review. IFC Bulletin., 2009 .

[13] D. P. Tsomocos, "Equilibrium analysis, banking and financial instability," J. Math. Econ., vol. 39(5), pp. 619-655, 2003, doi: https://doi.org/10.1016/S0304-4068(03)000454.

[14] C. Albulescu, "Forecasting The Romanian Financial System Stability Using A Stochastic Simulation ModeL," J. Econ. Forecast., vol. 13, pp. 81-98, 2010.

[15] International Monetary Fund, "Financial Soundness Indicators and the IMF," 2019, doi: https://www.imf.org/external/np/sta/fsi/eng/fsi.h tm. 
[16] X. Freixas and K. Ma, "Banking Competition and Stability: The Role of Leverage.," SSRN Electron. J., 2014, doi: https://doi.org/10.2139/ssrn.2488426.

[17] M. Dumicic, "Financial Stability Indicators The Case of Croatia," J. Cent. Bank. Theory Pract., vol. 5, 2016, doi: https://doi.org/10.1515/jcbtp-2016-0006.

[18] M. Basurto and C. Goodhart, "Banking Stability Measures," IMF Work. Pap., vol. 09, 2009, doi: https://doi.org/10.5089/9781451871517.001.

[19] World Bank, "Financial Stability https://www.worldbank.org/en/publication/gfdr/ gfdr-2016/background/financial-stability," World Bank, 2021. .

[20] A. Christopoulos, M. John, and D. Pavlos, "Could Lehman Brothers' Collapse Be Anticipated? An Examination Using CAMELS Rating System.," Int. Bus. Res., vol. 4, 2011, doi: https://doi.org/10.5539/ibr.v4n2p11.

[21] K. Männasoo and D. G. Mayes, "Explaining bank distress in Eastern European transition economies," J. Bank. Financ., vol. 33(2), pp. 244-253, 2009, doi: https://doi.org/10.1016/j.jbankfin.2008.07.016.

[22] A. Shaddady and T. Moore, "Investigation of the effects of financial regulation and supervision on bank stability: The application of CAMELS-DEA to quantile regressions," J. Int. Financ. Mark. Institutions Money, vol. 58, pp. 96-116, 2019 , doi: https://doi.org/10.1016/j.intfin.2018.09.006.

[23] J. H. Boyd and D. E. Runkle, "Size and performance of banking firms: Testing the predictions of theory," J. Monet. Econ., vol. 31(1), pp. 47-67, 1993, doi: https://doi.org/10.1016/0304-3932(93)90016-9.

[24] A. S. Shinde and K. C. Takale, "Study of BlackScholes Model and its Applications," Procedia Eng., vol. 38, pp. 270-279, 2012, doi: https://doi.org/10.1016/j.proeng.2012.06.035.

[25] J. Hull, I. Nelken, and A. White, "Merton's Model, Credit Risk and Volatility Skews," J. Credit Risk, vol. 1, 2005, doi: https://doi.org/10.21314/JCR.2005.004.

[26] P. Radkov, "Measuring default risk of Bulgarian public banks with Merton model," 2013, doi: https://doi.org/10.13140/2.1.3244.3524.

[27] I.-R. Diaconu and D.-C. Oanea, "Determinants of Bank's Stability. Evidence from CreditCoop," Procedia Econ. Financ., vol. 32, pp. 488-495, 2015, doi: https://doi.org/10.1016/S2212-5671(15)01422-
7.

[28] R. Barr, K. Killgo, T. Siems, and S. Zimmel, "Evaluating the Productive Efficiency and Performance of U.S. Commercial Banks. Federal Reserve Bank of Dallas," Financ. Ind. Stud. Work. Pap., vol. 28, 1999, doi: https://doi.org/10.1108/03074350210767988.

[29] Bank Perkrreditan Rakyat, "SE OJK No. 39/SEOJK.03/2017 Tentang Laporan Tahunan Dan Laporan Keuangan Publikasi Bank Perkreditan Rakyat,” 2017. 